ChAPter 13

\title{
The Warsaw Inferno
}

Tuesday morning, 1 August 1944, as I remember, was warm and rather humid, with hazy sunshine. The thunder of heavy guns could be heard in Anin, and it came closer with every hour; surely this was a clear indication of an early end to my ordeal. After years of struggle and going in daily fear for my life, I was about to be freed. I could hardly believe it; I was so excited that my head kept spinning around. It also occurred to me that it was ten days before my thirteenth birthday, a significant event in the life of a Jewish boy. The occasion, known as a Bar Mitzvah, marks the day a Jewish boy undertakes the obligation to keep all 613 precepts, between Man and God and Man and Man, like an adult. The best birthday present I could possibly have would be to celebrate my Bar Mitzvah in freedom.

Early that morning, my sister arrived unexpectedly in Anin in an exuberant mood. Tuesday was not a day she normally came to visit, but on this day she couldn't get there quickly enough, she was so excited to tell me that the Germans were in full retreat from Warsaw, and liberation could be only a matter of hours away. "Stefciu," she said, "we have cheated the Nazis and survived — this calls for a real celebration!" And as there was no need for me to hide anymore, she said, we would set out for central Warsaw together to explore the big city and await the entry of the triumphant Red Army, to experience there the never-to-be-forgotten moment of our liberation. I got ready in no time at all, and we bade a brief farewell to Pani and Wanda, planning to be back later in the day. What's more, Wanda raised a smile and even warmed up to me; perhaps her not-so-friendly attitude had been due to nothing more than acute fear. We promised Pani that I would be back with her that evening, or the next day at the latest. We were sure that when we returned it would be as free people, at liberty to come and go as we pleased.

It was very exhilarating to be out and about in the open. We boarded the bright-red painted "Kolejka" suburban electric train from Anin-Wawer 
to central Warsaw. It was all very exciting. I looked forward to exploring the capital, which I had only seen briefly before, with my sister. We crossed the broad Vistula via a lattice bridge that connected Praga with the main part of Warsaw. On the way, we could see German military vehicles in headlong retreat across the Vistula bridges, all going the same way, from east to west. When we reached the city centre, there were far fewer Germans in evidence, with only the odd military vehicle speeding past, fleeing in dread of the avenging Russians. It was a marvellous sight. I had often wondered if this day would ever come, and what it would be like to see the hitherto invincible Wehrmacht turning tail. While mingling with the crowd, I remained as always on my guard. Wala tried to impress upon me that I could relax.

"Stefciu," she said, "there's nothing more to fear, and no need to shy away from people! The Germans are on their way out, and the shmaltzovnik Jew-hunters are now out of business. They can't touch us anymore!"

I could only answer, "I know, but it will take some time for me to get used to it." For almost three years now, I'd had to avoid people, making myself as invisible as possible by keeping out of sight. Wala was far more confident than I, and had a nice demeanour about her; she was good at mixing with people, especially now that the Nazis were as good as gone.

Wala knew Warsaw well, and she showed me the sights. We explored the capital together with carefree abandon, jumping on and off the running-boards of street trams out of sheer excitement at being alive and free. I felt like a slave who had just been unchained. I had never been to downtown Warsaw before-it was beautiful. I was bewildered by the busy, crowded streets, the tram cars, the impressive buildings, the majestic palaces and old castles, and the historic Old Town area. It felt as if it was all a dream. Soon after, though, we noticed that some feverish activity had begun; young men and women were scurrying about the streets purposefully, as if running messages. Later that afternoon, the streets began to clear and grew almost deserted, as if everyone was responding to a signal. A deceptive calm descended on the city and even the big Russian guns seemed to have fallen silent—it was the lull before the storm.

Surely, there had to be something in the air. There must be some reason for all this frantic activity, we assumed. These people must know 
something that we don't. We decided that perhaps we should also abandon the streets and try to take cover. Somehow, it never occurred to us to return to Anin. Wala suggested that we look up a friend of hers who happened to be living nearby and avail ourselves of his hospitality, and at the same time try to find out what was afoot. To my utter surprise the "friend" turned out to be a Polish police officer, the very sort of person I always tried to keep clear of! Confronted by a "Navy-Blue" in the open door, my first instinct was to turn tail and run. Wala, unlike the scared, untrusting animal that I was, took these things in her stride. They were perfectly normal to her, and so she had failed to warn me. Bolesław Piatkowski had been introduced to her as a sympathetic friend by our cousin Franka Fajngold, who went by the grand name of Apollonia Szybowska; she had the colourful personality to match the name. "Apollonia" had by now been seized as an "Aryan" on a Warsaw street and sent for forced labour in Germany. Rather surprised to find us at his door at this hour, Bolesław, or Bolek as he liked to be called, nonetheless greeted us warmly and didn't hesitate to invite us into his apartment on Ulica Wolska, in the Wola district of Warsaw. We were also delighted to be introduced to his charming wife and their teenage son. Bolek Piatkowski was a liberal-minded person, and as an avowed anti-Nazi, he was favourably disposed to Jews. As a rule, Polish policemen by their very nature were reactionary and hostile to Jews, so it was rare indeed to find the likes of police officer Piatkowski in the ranks of the "Navy-Blues." For a policeman he was atypical; he was both a passionate Polish patriot and a good socialist. We had a nice feeling about him, and suspected him of belonging to the Armia Ludowa, the clandestine left-wing People's Army.

Wala asked Bolek if there was anything afoot out in the street. "Yes, there certainly is," he replied. "We are expecting a call to arms at any moment that will trigger an armed uprising all over the capital!" Apparently, this was not a very well kept secret, but Wala had had no inkling of it, and nor had Pani Gozdzialska in Anin. Soon after, Bolek went and changed into his civvies, and Madame Piatkowka invited us to join the family for afternoon tea in the salon. I thoroughly enjoyed the delicious home-made shortcake biscuits and the traditional Polish babka cake, which I hadn't had in a long time. Sitting around the table, we tried our best to relax by making small talk, but it was difficult to hide the state of suspense we were in, and the conversation inevitably turned to the 
subject of the explosion that was about to erupt. At exactly five in the afternoon our conversation was cut short by sudden bursts of small-arms fire, and we turned deathly silent, just looking at each other. Soon after, Officer Piatkowski stood up to his full height. He was tall and imposing, and on leaving the table he said in a grave voice that he was sure the insurgency had started. "This is it! It's begun," he said. He went into another room and produced a hitherto banned Polish national flag, which had been hidden since the war began, and unfurled it from the balcony railing.

In no time at all other people, up and down the street, did the same, and put out their red and white flags, hanging them from flagpoles and out of windows. What a marvellous and stirring sight it was! We were going to teach those darned Jerries a lesson they would never forget! Bolek fetched his service rifle and slipped a white-and-red armband over the left sleeve of his civilian jacket, saying he had orders to report to his unit. Bolesław Piatkowski then bade his wife and us a hasty farewell, confidently expecting to be back before long. As he reached the door, he turned back and said to my sister, "Walusia,"that is what he called her- "it would not be safe for you to try and get back to Anin now. You and Stefek are welcome to remain in our home until the danger is over." And as a parting gesture, with his voice full of emotion, he said: "You have nothing more to fear as Jews. Warsaw will soon be free and things are about to change. There will emerge a new Poland, a better and just Poland for all!" We were very touched by what he said, and tears came to our eyes, especially those of Wala, who is easily moved. We realised that he must be an officer in the resistance and therefore must know what he is talking about. Bolek then turned towards the door and promptly left the apartment, taking his teenage son with him. That night a welcome shower fell on the city after a warm and sultry afternoon. During the evening the firing died down somewhat, and we had a reasonably quiet night. However, we were far too excited to get much sleep.

Now that the uprising had started, we were sure that by morning the Russians would have crossed the Vistula to relieve the capital and be welcomed with open arms by the entire population. But when morning came, there was no sign of the Russians. The shooting became more intense, echoing all around us, from the nearby streets. Later on, heavier arms also came into play and loud explosions could be heard from near 
and far, but we didn't know how things were progressing. Were we winning? Over the next couple of days, the surrounding streets resonated with the ever-increasing sound of gunfire. To our dismay, Warsaw was now fully caught up in the uprising and we, trapped in Wola, turned out to be in the thick of it. That district was to experience some of the initial and most bitter fighting of the entire uprising. And still, days later, there was no sign of the Russians. Our dream of imminent liberation began to fade rapidly.

One of the reasons we had decided to travel to central Warsaw was that in the event of any heavy fighting between the Russians and Germans it was considered safer to be in the big city. We knew that liberation was imminent, but had heard nothing about a possible uprising. We also wanted so much to experience first-hand the triumphal entry of the Red Army into the capital. There was no going back now to the safety of the Gozdzialska home, and it began to look as if we would have cause to regret our hasty decision on that auspicious morning. Unknown to us at the time, on the very day we left Anin an advance column of Russian tanks, racing from the north-east, reached the outskirts of Praga, right next door to Anin. Had we stayed there, we would have come close to gaining our freedom that day. This Russian forward column was either ordered to pull back or forced to retreat by the German forces, but had we stayed, we would have at least been on the right side of the Vistula and that much closer to the Russian lines, with no wide-flowing river to separate us.

The Armia Krajowa, the national Home Army. had timed their uprising to start as the Red Army's General Konstantin Rokossovsky, who was of Polish origin, was at the gates of the capital and the liberation of the city was a foregone conclusion. By then there were few Germans left in evidence and it took the insurgents little time to take control of a large part of the city at great cost, apart from some pockets of stubborn German resistance. The intention of the Armia Krajowa (AK) was to beat the Russians to the punch and wrest the capital from the Germans. They intended to score a military as well as political victory by taking control of the capital and asserting their independence in the name of the Polish Government-in-Exile in London. It was they who orchestrated the uprising and who gave the order for the uprising to begin without consulting Moscow, thereby irking Stalin. The AK was under the direction of the London Poles, who were strongly opposed to Soviet Russia, which made matters worse. 
The AK was politically on the right, and apart from being implacable enemies of the Russians, many of its members were also anti-Semitic. It is well documented that the AK leadership ridiculed the Jews' fighting ability and didn't want them in their ranks. When Jewish fighting units appealed to them for arms during the Warsaw Ghetto uprising, they considered arming them a waste of good weapons, although arms were in fact purchased from Polish sources. General Tadeusz "Bor" Komorowski, the AK commander-in-chief, in a report to his men in the field in 1943, ordered them to kill Jews sheltering in the forests, whom he labelled "bandits." He was referring to Jewish partisans operating in the forests of eastern Poland, who had no option but to raid villages for food, and if necessary to use force if the peasants didn't part with it willingly. Whenever NSZ Polish fascist bands and even certain AK renegade units came across groups of Jews in the forests they would try to disarm and kill them. Paradoxically, the Polish nationalist NSZ was as intent on killing Jews as Germans.

A number of surviving Jewish fighters from the Warsaw ghetto uprising the previous year, as well as others who had emerged from hiding, seized this opportunity to join their compatriots in their momentous struggle. All these young men asked for was a weapon so they could fight shoulder-to-shoulder with their allies against their common enemy and avenge their families. Although the AK didn't as a rule accept Jews into its ranks, during the uprising they were somewhat tolerated in certain units, depending on the attitudes of their commanding officers. The much smaller socialist AL (Armia Ludowa) or People's Army, which more readily accepted Jews into its ranks, made common cause with the $\mathrm{AK}$ and fought alongside them during the uprising, but had previously acted independently and were otherwise ideologically opposed to them. Sadly, most of the Jews taking part in the uprising were killed in the fighting that ensued. Ironically, they died as Poles, not daring to divulge their Jewish origin.

Not long after the uprising began, the Red Army reached the east bank of the Vistula, and there they halted. Although poised to cross the river, the Russians made no move. Had my sister and I stayed behind in Anin, we would have been freed in a matter of weeks. For us, freedom lay just across the Vistula, but well beyond our reach. Our impulsive trip to Warsaw would turn out to be premature and an unfortunate 
mistake, a nightmare that was to prolong the war for us by almost another six months, six months of going in daily fear for our lives. I was not destined to celebrate my Bar Mitzvah, after all, undergoing a baptism of fire instead. And having been cut off from my safe-house, I had no prospect to replace Pani Gozdzialska: such people were difficult to locate. The uprising also spread to Praga, but it never amounted to much and only lasted a short time, with the Red Army arriving there by early September, as we later discovered.

Stalin's decision not to press on with the offensive beyond the Vistula was essentially political, to enable the Germans to put down the uprising that was staged by Polish patriots who were opposed to the Russians. The rising, as I mentioned, was authorised by the Polish government in London, which was considered reactionary by the Kremlin. The official Russian explanation for holding back was that the troops were exhausted after the breathtaking offensive that had begun more than two months earlier, in June 1944. By now their advance had lost its momentum, and they needed time to bring up reinforcements before the next big push. On the other hand, if their only aim was to see the uprising crushed, they needed to stall no more than a few weeks. And surely they didn't need months to regroup and bring up supplies.

Perhaps the real reason was that Stalin wanted the British and Americans, after Normandy, to lessen the pressure on his forces, as so far the Red Army had borne the brunt of the fighting. We shall never know the whole truth. What is certain is that Stalin's regrettable decision to halt the advance was to prolong the war considerably, resulting in numerous casualties.

Meanwhile, all around our apartment block in Wola, more intense fighting erupted in the following days. There was close combat and determined attacks against the German pockets still holding out. As Luftwaffe Stuka dive-bombers appeared in the skies with their screaming sirens, it became too dangerous to remain in the apartment, so we ran for cover into the internal corridor or the basement, together with the other occupants of the block. Bombs whistled before they fell, exploding all around. Our apartment block shook and the windows rattled, but luckily there was no direct hit. The shelter was crammed full of people, and nobody cared who we were. In all that chaos, no one paid attention to us, or noticed that we didn't belong in the building or thought we might be Jews; there was a strong feeling of solidarity at 
this time. It wasn't so unusual to see strangers in a shelter-others had also found themselves cut off from their homes by the sudden outbreak of fighting, or they may have come from nearby bombed-out buildings to seek shelter. The atmosphere in the basement was friendly; morale was good and most of the people were in high spirits, joking and putting on a brave face. However, some were so afraid that they kept praying constantly, repeating "Mother of Mercy" and so on. Old women made the sign of the cross after every loud explosion; others kept cursing the Swabians (Germans). The more optimistic among them, especially the men, felt sure it would all end in a decisive Polish victory. "Soon it will be over. With the Russians so near, the uprising can't last," they confidently predicted. As the sporadic aerial bombardment stopped, we returned to the apartment, which had its window-panes blown out. Shards of glass were strewn all over the place. Wala and I helped Pani Piatkowska clear up the mess until we next had to run for cover at the next loud cry of, "Everyone to the basement, to the cellar!"

At night the sky was illuminated by burning buildings and German searchlight beams. Long chains of tracer bullets streaked through the night sky, coming from German anti-aircraft batteries positioned somewhere outside Warsaw. They must have been directing their fire at the RAF planes that came over by night to drop supplies to the insurgents. It is significant that there had been no such Allied support held out to the embattled defenders during the Warsaw ghetto uprising earlier, when the doomed and poorly-armed inhabitants rose up against much greater odds. Perhaps it would have made little difference to the outcome, but a show of support would at least have demonstrated Allied concern for the fighters and sent the right message to Hitler. Any visible act of support by the Allied Powers would have given heart to those lost in despair.

Some German units that had previously retreated, now realising that the Red Army had halted its advance and was not poised to cross the Vistula, started to come back, bringing up reinforcements, including heavy armour and turning on the people of Warsaw with savage vengeance. The situation, which had looked so hopeful only days before, had now taken a distinct turn for the worse. Our initial euphoria was short lived, and evaporated completely as the Germans started to regain the initiative. We would again be forced to hide our identity and go in fear of our lives, not only because we were Jews, but because of the uprising 
as well. My sister started to reproach herself for having brought me to Warsaw.

As luck would have it, we found ourselves in the worst possible locality: as the district of Wola was on the western approaches to Warsaw, it took the German forces no more than a week to reach our vicinity. It was in Wola that some of the worst revenge atrocities against the civilian population took place. We were sheltering in a block of flats opposite what had once been a Jewish hospital and was now a hospital for the general population. It was marked with a large red cross, and we hoped we would be protected from bombardment by its proximity, but it made no difference whatsoever. The Nazis didn't respect any international conventions. In fact, they later shot many of the injured and set the Wola hospital ablaze, with the patients inside.

During the course of the fighting, the Germans began to use a frightening new weapon, the sound of which we hadn't heard before. It was a heavy rocket-launcher that could fire up to six projectiles. At first it made a whining and cranking noise, as if the motor was winding up before firing, and then there was a piercing shriek and moments later the thunderous explosion. It was aptly named "Krowa" (bellowing cow) on account of the sound it made. It was in fact called Nebelwerfer, or fog-thrower, by the Germans. There was now fierce house-to-house fighting all around us.

On one occasion, someone shouted hysterically, "German tanks, German tanks!" Peering out of a window, I saw a pair of Panzer tanks position themselves at the top of our street with their gun turrets rotating menacingly from side to side, looking for a target. We quickly made for the inner landing, where we thought it safer. The defenders opened up with everything they had from behind their barricades, which had been hastily constructed from overturned trams and torn-up paving slabs. Others hurled Molotov cocktails-bottles filled with keroseneout of apartment windows at the German armour in the street below. We were now crouching, crammed in with others, at the bottom of the staircase. In a show of bravado, someone was hanging out of a window on an upper floor and relaying a running commentary on the progress of the fighting to those inside on the upper stories. This in turn was relayed all the way down the stairway. A loud cheer went up and spread through the building as someone shouted excitedly, "A German tank's on fire!" It was even rumoured that our forces had managed to capture 
German tanks and turn them on the enemy. Now and then we heard the terrifying shriek of the Nebelwerfer, as someone would shout "Krowa!" and everyone braced himself, head between his knees, for the loud explosion to follow. Then someone would shout, "Oh, Jesus, that was close!" One could never know where the projectile would land.

Our building had by this time been badly damaged by the shelling. Deafening explosions were becoming more and more frequent, with debris raining down on us. Our hair was white from the plaster dust that had come down as Wala and I pressed our way down the corridor, to the stairwell then down into the basement. Everyone scurried to and fro in the smoke-filled building, seeking shelter wherever we thought we might be safer, but soon the basement and the entire building became unsafe as the block was hit with incendiary shells and fires began everywhere. Covered in dust and grit, enveloped in smoke, we ran out into the street as charred timbers and plaster fell from the ceilings, and we got separated from Mrs. Piatkowska. Had we remained in the building, we would most certainly have been buried alive. Wala and I ran from doorway to doorway and house to house, keeping close to the walls. Now and then we paused momentarily to decide on the next objective to aim for before running again. There was firing from all sides, with total mayhem around us. It was difficult to decide where to go. We wanted to get away as far as possible from the buildings which were the target of German tank and artillery fire, so we aimed for a nearby grassy square with trees and bushes, which seemed like a good refuge, clear of the crumbling walls and exploding shrapnel.

We ran in the pouring rain-which was at least a welcome relief from the heat of recent days-sidestepping corpses lying in our path as bullets whistled around us and over our heads with a resounding echo. Bent forward, we made for a mound of earth with a cluster of trees around it. While we were running, a depression in the earth appeared on the sodden path in front of us and we instinctively tumbled down into it, breathing a sigh of relief. When we opened our eyes and regained our breaths, we realised what a terrible mistake we had made: the waterlogged pit turned out to be a foxhole and machine-gun nest manned by a unit of resistance fighters. Some of the young men tried to bravely raise a smile; others simply ignored us and carried on shooting through their firing-points at the German positions. The Germans, in turn, were directing their much greater fire-power towards us, and all hell broke 
loose. My sister and I were terror-stricken. We looked at each other in astonishment and knew we couldn't possibly remain there-we had to get out, and quickly. We were sure these brave and desperate men were about to be overwhelmed and perish to a man, together with us. "Dear God, please don't let us die like this, an anonymous and lonely death," I was thinking. We were terrified at the thought of dying as unknown Poles, buried alive under the ruins of Warsaw. To perish in this way, without a trace, was unthinkable. We had struggled and survived this far; we had to live on to tell the story!

We stayed pinned down, waiting for a lull in the shooting before making a dash for it. I stuck my head out slowly at the first opportunity, when the barrage had somewhat died down, and then we scrambled out of the hole, crouching and half-crawling in the rain and mud, aiming for a row of houses on the opposite side of the green. Some of the houses had flames rising from them; others had smoke billowing out of the windows. While we were running, shooting erupted again and became more intense; we seemed to have run into a hail of bullets, with machine-gun volleys coming from different directions. I was out in front, with Wala following close behind, trying to keep up. Bullets whizzed past us-it was a miracle we weren't hit. Suddenly, several crazed Germans with their sleeves rolled-up appeared out of nowhere. They looked fierce in their steel helmets; their uniforms covered in sweat and grime, with stick-grenades tucked under their belts and Schmeisser machine-pistols pointing at us. It seemed we'd been running towards German-held lines. I froze to the ground and quickly threw my hands up before they had time to shout "Haende hoch." I was petrified, and my heart pounded wildly. I had not experienced such dark fear since my time in the ghetto and brickyard. I had been in this sort of situation before, with death staring me in the face and my brief life flashing before my eyes. I couldn't believe it was happening to me again.

We got ourselves into this mess simply because of an ill-fated short train-ride to Warsaw. I was never meant to be here at all. Nonetheless, here I was, with my sister, in the same sort of tight spot from which there was no escape, with frenzied Germans levelling their guns at us menacingly. To our utter horror, we were caught by Waffen-SS troops, conspicuous from the twin lightning bolts on their helmets and the death's-head insignia on their uniforms. The task of putting down the uprising had been entrusted to the elite Waffen-SS, and in particular, 
the responsibility of crushing the resistance in Wola was assigned to the notorious SS-Dirlewanger detachment.

For whatever reason, we were spared, although it was a near thing. The Germans forced us at gunpoint through the ruins to join other captives at an assembly point farther away from the fighting. Any young male prisoners were picked out; those with injuries were particularly likely to be deemed what the Germans called "bandits," and presumably executed. We spent the rest of that day and night under guard in the open, sitting or lying on the ground. Early the next morning we were made to join up with an even larger stream of women, children, and old people in a long column winding its way past the smouldering ruins, not knowing where to. We were escorted by Waffen-SS troops and Ukrainians. The latter, traditional enemies of the Poles, were particularly cruel. Had we fallen into their hands it would have been the end. There were rumours going round of people being burnt on pyres. The deserted streets we passed had been captured from the insurgents. We had to pause here and there while sappers systematically detonated buildings in our path. Walls came crashing to the ground in front of us in a huge cloud of falling debris and dust before our column could proceed further. Other houses were torched with flame-throwers, block by block. The world around us was like an inferno; the smell of acrid smoke and dust stung the eyes and made them water, and all the time that searing August heat bore down on us, with the sun almost obscured by the haze. The elderly and infirm cried out for water, while the young and strong endured in silence. The stench from unburied and bloated corpses lying in the scorching heat, combined with the smell of gunpowder and choking dust, was nauseating.

Strangely enough, in this inferno my sister and I felt somewhat safer, relieved not to be singled out as Jews. I must admit that we even derived a certain schadenfreude from seeing Poles treated like Jews, driven like cattle through the streets the way Jews had been herded, beaten down and hardly saying a word. We were now in the same plight as all the other inhabitants of Warsaw, as they too were now snaking their way out of their hometown in a long line, stripped of their wealth and possessions, carrying only what they had on their person. Some carried bundles and sacks on their backs, but we had absolutely nothing to carry. This was so reminiscent of when we had first been evicted from our home and forced into the crowded ghetto more than two years 
before. How ironic. For the first time we were equal, suffering not as Jews but as Poles. Being part of the wider population and sharing the same fate as the other inhabitants gave us a measure of security, and in this fiery hell, no one would think of pointing an accusing finger at a Jew. Poles now also had a taste of what it was like to be at the receiving end of Nazi brutality and retribution.

Hungry, thirsty, and suffering from exhaustion, we continued to be herded along the rubble-strewn streets without knowing our destination or fate. As we passed through a certain neighbourhood, we noticed that the streets were littered with leaflets. The escorting soldiers warned us that it was verboten to pick them up, pointing to the sky to intimate that they were dropped from the air by "enemy aircraft." Wala warned me to obey, but as usual curiosity got the better of me, and when I thought the soldier near us was distracted, I couldn't resist picking one up. The bold headline had caught my eye. The leaflet, printed in Polish, shocked us to the core. We couldn't believe what we were reading; coming at a time like this the leaflet's message was particularly hurtful:

\section{CITIZENS OF WARSAW! \\ We are fighting for a \\ FREE POLAND}

\section{A Poland without Germans, Russians and Jews}

A Poland without Jews! We were horrified-what were we, if not Poles? More recently, or at least since the Ghetto and Warsaw uprisings, we thought that Poles and Jews were in this together, confronting the same cruel enemy. But we must have been wrong. Coming at a time like this, such declaration was the final betrayal. We feared that when the Nazis were gone the danger for us would remain. Was this the beginning of the New Poland that Bolek Piatkowski had promised us? Wala quickly threw away the leaflet without reading the rest. What we'd seen was enough. This was the Poles' darkest hour. The country was bleeding and Warsaw was dying, with the capital levelled to the ground and its inhabitants killed by the thousands. And yet, its chauvinistic leaders considered it imperative to vilify the Jews at this time, though they were fully aware that Polish Jewry was no more and that their dream of a Poland without Jews had already come true. The leaflets were 
scattered over a wide area that was in German hands, now that the inhabitants had been driven out. The way they lay scattered on the ground, the leaflets could not have been dispersed by hand, nor blown about by the wind. They could have only rained down from above. Since the Home Army had no planes, these must have been dropped from the RAF aircraft flown by Polish aircrews that came over almost nightly to drop supplies. It was inconceivable that at this grave hour the anti-Semitic Polish "old guard" in London should consider Polish Jews their implacable enemies, alongside the Germans and Russians.

Eventually, we reached a large open area outside Warsaw where we were ordered into a massive barbed-wire enclosure together with thousands of other evacuees from Warsaw. We were penned in on all sides by barbed-wire entanglements thrown across a grassy field against a hillside. There we were formed into different groups, reminiscent of a medieval field of battle, with columns of people constantly marshalled about. Men were segregated from women and children and put into different enclosures. I was just thirteen, and still boyish enough to be left with my sister among the women while the Germans looked for any young men who may have been involved in the uprising. We were kept in this vast field without food and drink. People were desperate, and cried out for water. The Germans didn't understand any Polish, or perhaps they simply didn't want to. Women and children learned to beg for water in German. "Wasser bitte, Wasser bitte," they pleaded. Eventually water arrived by army tanker. It was hot and humid, and the people had gone without water for many, many hours. Some had fainted, overcome with heat exhaustion. When the tanker finally approached, there was a mad rush to get to it. Some got trampled in the rush. The more stoic among the prisoners tried to restrain the others, shouting, "Polacy! Polacy!" But listening to this appealing to their patriotism as Poles, restraining themselves, was easier said than done, when they were going almost insane with thirst in that heat.

Additional prisoners were continuously herded into the stockade. Wala and I tried to keep as near as possible to the makeshift gate, looking for an opportunity to escape. As the barrier was lifted to let yet another column of people in, pushing and jostling broke out, and in the commotion Wala seized the chance and pushed me forward, past the gate. I made a dash for the nearby bushes for cover, hoping she 
would follow, but she was forced back and didn't manage to make it past the gate. I panicked at the thought of being separated from my sister again. In the mêlée I lost sight of her, and I waited there, forlornly looking towards the mass of people in the enclosure, hoping to catch a glimpse of her and praying that she would somehow manage to escape. Fortunately, the next day the Germans started to release women with children, and luckily Wala had managed to place herself amongst them. I could see her as she slipped past the gate holding a "borrowed" child in her arms. Some women with two or more children would lend them to total strangers to enable them to get away-some people were like that during the war. Again we were very fortunate, as most of the young men and women were transported to the Reich for forced labour. Had Wala been taken away, I don't know if I would have been able to survive on my own.

Meanwhile, it took the Germans just two months to put down the uprising, ruthlessly driving out the Warsaw population and razing the city to the ground, as expressly ordered by Hitler, with the details entrusted to Reichsfürer-SS Himmler. And when it was all over, Himmler apparently reported back to Hitler, "Warsaw has ceased to exist." The uprising, it transpired, was a tragic blunder, and had been doomed from the start. Were it not for the uprising, the Russians would not have halted on the Vistula. They apparently had orders to advance beyond Warsaw, and with the Germans in headlong retreat, there was little to stop them. The ill-advised Polish decision to rise up at this time had changed the situation completely. As a result, the Russians decided to break off their offensive, thereby prolonging the war considerably. This catastrophe resulted in incalculable loss of life. Apart from the terrible carnage in Warsaw, the situation enabled the Nazis to operate their death camps in Poland for several more months. 


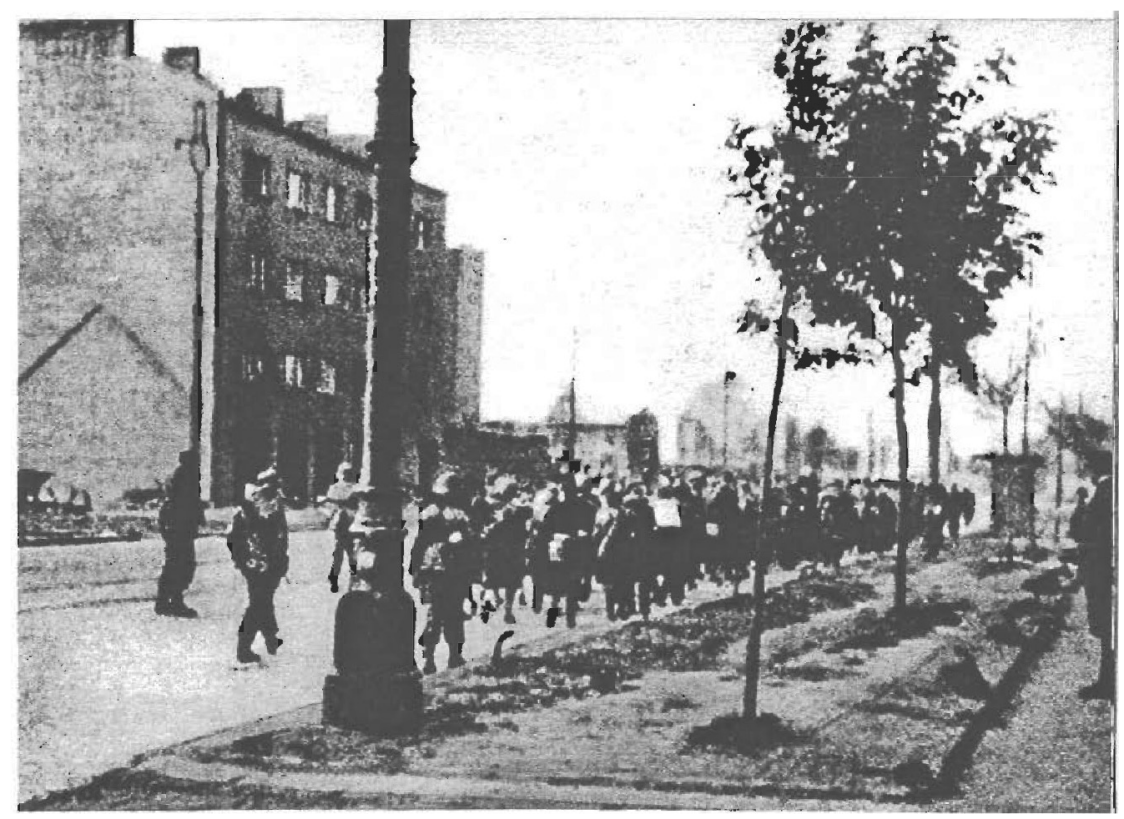

SYG Archives

People escorted out of Warsaw under armed guard during the uprising. 